\title{
EHMTI-0290. Headaches in patients with autism spectrum disorder
}

\author{
M Victorio \\ From 4th European Headache and Migraine Trust International Congress: EHMTIC 2014 \\ Copenhagen, Denmark. 18-21 September 2014
}

\section{Introduction}

Autism Spectrum Disorder (ASD) is a neurodevelopmental condition characterized by persistent deficits in social communication, social interaction and restricted, repetitive patterns of behavior, interests or activities. In general, ASD is associated with pain insensitivity and self-injurious behavior. Support for these associated traits are derived mostly from anecdotal and clinical observations. Headache disorders like migraine can be a disabling condition but none has been reported among individuals with ASD.

\section{Aims}

To characterize the headache types experienced by patients with ASD and review their clinical profile.

\section{Methods}

A retrospective chart review of patients with ASD who presented in the neurology clinic from January 2011 to April 2013 was performed.

\section{Results}

Eighteen patients were identified, 12 males and 6 females. Migraine was the most frequent headache type occurring in up to $61 \%(11 / 18)$ of patients. Eight of these 11 patients have migraine without aura; one with migraine with aura and two patients have both migraine with and without aura. Combined migraine and tension type headache was seen in 3 patients. Three had chronic daily headache and one had probable migraine. Age at presentation ranged from 5-16 years. All patients were verbal and all have co-morbid behavioral and mental health conditions.

\section{Conclusion}

Our data show that ASD patients, despite being known to have indifference to pain, can experience headaches; with migraine being the most common headache type in these patients referred in our neurology clinic.

No conflict of interest.

Published: 18 September 2014

doi:10.1186/1129-2377-15-S1-B37

Cite this article as: Victorio: EHMTI-0290. Headaches in patients with autism spectrum disorder. The Journal of Headache and Pain 201415 (Suppl 1):B37.
Submit your manuscript to a SpringerOpen ${ }^{\circ}$ journal and benefit from:

- Convenient online submission

- Rigorous peer review

- Immediate publication on acceptance

- Open access: articles freely available online

- High visibility within the field

- Retaining the copyright to your article

\section{SpringerOpen $^{\circ}$}

(C) 2014 Victorio; licensee Springer. This is an Open Access article distributed under the terms of the Creative Commons Attribution License (http://creativecommons.org/licenses/by/2.0), which permits unrestricted use, distribution, and reproduction in any medium, provided the original work is properly cited. 